\title{
Transvenous lung biopsy in the pig
}

\author{
MOHSIN HAKIM, PETER G I STOVIN, TERENCE A H ENGLISH, \\ JOHN WALLWORK
}

\begin{abstract}
From the Department of Cardiothoracic Surgery and Pathology, Papworth Hospital, Papworth Everard, Cambridge
\end{abstract}

ABSTRACT At present there is no satisfactory technique for repeated lung biopsy in recipients of heart-lung transplants. A new technique for lung biopsy, which might be adopted for this purpose, $\mathscr{\odot}$ has been developed. A Teflon sheath is inserted through the jugular vein into the pulmonary artery with the aid of a balloon catheter. A flexible biopsy forceps is then introduced through the sheath 9 into the pulmonary arterial tree and advanced into the periphery of the lung, where biopsy samples $\vec{\nabla}$ are taken. The procedure was attempted in 14 pigs. Initially crocodile jaw (two pigs) and fenestrated $\odot$ cups forceps (five pigs), which are currently in use for transbronchial lung biopsy, were used. $\stackrel{\Phi}{3}$ Subsequently the biopsy forceps was modified and the jaws were replaced by a cutting needle ${ }_{\mathscr{\Phi}}$ mechanism (six pigs). Out of the 13 animals in which the procedure was technically possible, lung parenchyma was obtained from nine and pulmonary arterial wall from 11 . One animal died shortly $\vec{D}_{\mathscr{D}}$ after the procedure. The cause of death could not be determined with certainty at postmortem examination. There was, however, a small tear on the surface of the lung, which could have pro-duced a tension pneumothorax. The other 12 animals recovered from the procedure. They were killed 24 hours later and postmortem examination was carried out. One animal in which the crocodile jaw forceps had been used had a haematoma in the lower lobe $(3 \times 3 \times 4 \mathrm{~cm})$ and $100 \mathrm{ml}$ of $\frac{\mathscr{O}}{\circ}$ blood in the pleural cavity. In the other 11 animals, in which the fenestrated cups or the cutting $\underset{\vec{F}}{\vec{\circ}}$ needle forceps had been used, the intrapulmonary haematomas were $1-2 \mathrm{~cm}$ in diameter and the pleural surface was intact. Tt is concluded therefore that transvenous lung biopsy is feasible and that $\frac{3}{2}$ this procedure might find an application in monitoring rejection in recipients of heart-lung transplants.

Early laboratory and clinical experience in heart-lung transplantation suggested a close correlation of rejection in the two organs. ${ }^{12}$ This concept was central to the management of recipients of heart-lung transplants, and has been the basis for using cardiac biopsy in the diagnosis of rejection in the combined graft. Recent experiments in primate heart-lung transplantation have, however, shown that significant pulmonary rejection leading to respiratory failure can occur in the absence of cardiac rejection. ${ }^{3}$ This has also occurred in clinical practice. ${ }^{4}$ Independent surveillance of lung rejection if practicable would therefore be a logical approach to this problem. This prompted us to explore the possibility of developing a simple technique for repeated lung biopsy that could be carried out with the same ease and frequency as

Address for reprint requests: Mr M Hakim, Department of Cardiothoracic Surgery, Papworth Hospital, Papworth Everard, Cambridge CB3 8RE.

Accepted 13 June 1986 transvenous cardiac biopsy. ${ }^{\supset}$ We considered that it $\stackrel{0}{\stackrel{2}{*}}$ should be possible to perform lung biopsy through $\frac{0}{7}$ the pulmonary arterial tree, with the bioptome introduced percutaneously through the internal jugular 0 vein into the right ventricle and then into the pulmonary artery. The technical challenge was, however, 오 considerable, and we had to prove that the procedure $\rightarrow$ would be safe and that the specimen obtained would be representative.

\section{Methods}

The first requirement was to develop a method whereby a flexible biopsy forceps could be introduced o into the pulmonary artery via the jugular vein. This was achieved by designing a Teflon sheath $40 \mathrm{~cm}$ long, $\stackrel{?}{?}$ with an internal diameter of $7 \mathrm{~F}$, mounted on a $60 \mathrm{~cm}$ 6F balloon catheter. After the assembly had been $\stackrel{\vec{D}}{\vec{D}}$ floated into the pulmonary artery the balloon catheter $\stackrel{\mathbb{Q}}{\stackrel{\oplus}{\oplus}}$ was removed, the end of the sheath being left in the $\stackrel{\mathbb{Q}}{\Omega}$ main pulmonary artery. The flexible biopsy forceps 


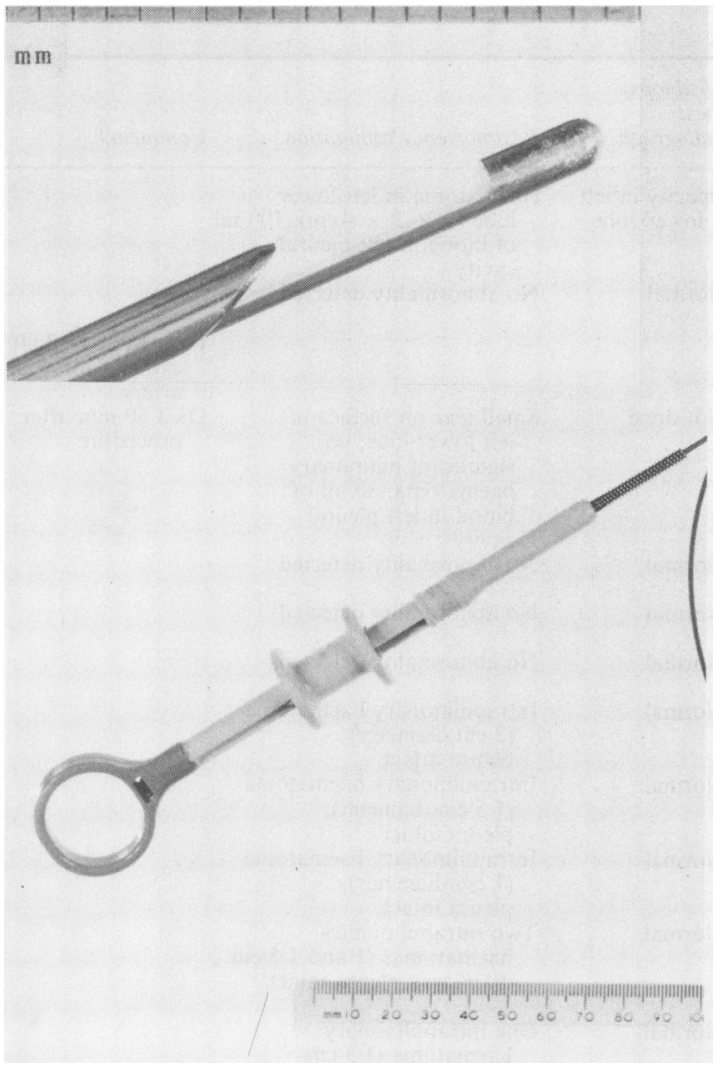

Fig 1 Modified flexible biopsy forceps with a cutting needle mechanism.

was then guided through the sheath into the distal pulmonary arterial tree.

The second requirement was to develop a biopsy mechanism that would yield a satisfactory specimen with minimal trauma to the pulmonary arteries and lung parenchyma. We initially used two types of flexible biopsy forceps that are currently used for transbronchial lung biopsy-crocodile jaw and fenestrated cups forceps.* The success rate in obtaining adequate samples was, however, low and the attendant trauma unacceptable. A new bioptome was therefore designed, in which a cutting needle mechanism is mounted on the end of a flexible forceps (fig 1). The total usable length of the forceps is $90 \mathrm{~cm}$ and the cutting end is $25 \mathrm{~mm}$ long in the closed position. The cutting end comprises a sleeve with external and internal diameters of 2 and $1.6 \mathrm{~mm}$. The end of

*Crocodile jaw forceps FB-15C (catalogue No 1008447) and fenestrated cups forceps FB-19C (catalogue No 1010974), Olympus-Japan (UK agent KEYMED, Stock Road, Southend-on-Sea, Essex SS2 5QH). the sleeve is bevelled with a cutting edge. Within the sleeve slides a probe with a biopsy notch $12 \mathrm{~mm}$ long and a rounded tip that forms the advancing end of the forceps.

Altogether transvenous lung biopsy was attempted on 14 pigs ( $35 \mathrm{~kg}$ in weight). General anaesthesia was by halothane delivered through a mask and spontaneous breathing was maintained. The animal was placed on the operating table in the lateral position with the right side up. The right external jugular vein was exposed in the neck with a short transverse incision. Through a purse string suture a Cordis introducer system $\dagger$ was inserted. The dilator of the Cordis system was then removed, a $10 \mathrm{~cm}$ long $9 \mathrm{~F}$ sleeve being left within the vein. The $40 \mathrm{~cm}$ Teflon sheath mounted on a $6 \mathrm{~F}$ balloon catheter was then inserted through the Cordis sleeve and floated into the left pulmonary artery. The balloon catheter was then removed and the end of the Teflon sheath was left in the pulmonary artery. The flexible biopsy forceps was then inserted through the sheath and advanced under radiographic control as far as possible until it engaged in a small peripheral artery. The biopsy mechanism was then activated with minimal withdrawal or advancement of the forceps. We attempted to obtain tissue as peripherally as was possible without damaging the pleura. Three or four specimens were obtained from each animal. Chest radiographs were done before and one hour after the procedure. The animals were killed 24 hours later and postmortem examination of the heart and lungs was carried out.

\section{Results (table)}

In one animal (pig 3) it was impossible to float the balloon catheter into the pulmonary artery. Lung parenchyma was obtained from nine of the other 13 animals. Pulmonary arterial wall was obtained from 11 animals (fig 2). One animal (pig 4) died half an hour after the procedure. Postmortem examination showed a small tear on the surface of the left lower lobe and the left pleural cavity contained $50 \mathrm{ml}$ of blood. The right lung and the heart were normal. The other 12 animals recovered satisfactorily from the procedure and none developed haemoptysis. Postmortem examination showed in pig No 1 a haematoma in the left lower lobe $(3 \times 3 \times 4 \mathrm{~cm})$ with $100 \mathrm{ml}$ of blood in the left pleural cavity. The biopsy had been carried out in this animal with the crocodile jaw forceps. The five animals in which the fenestrated cups forceps had been used developed small haematomas at the biopsy sites, about $2 \mathrm{~cm}$ in diameter. The cutting needle biopsy forceps was used in six animals and the intrapulmonary haematomas were

†Catalogue No 501-609D, Cordis Corporation, Miami, Florida 33152, USA 


\begin{tabular}{|c|c|c|c|c|c|}
\hline $\begin{array}{l}\text { Pig } \\
\text { No }\end{array}$ & Forceps used & Biopsy specimens & $\begin{array}{l}\text { Postbiopsy } \\
\text { chest } \\
\text { radiograph }\end{array}$ & Postmortem examination & Comments \\
\hline 1 & Crocodile jaw & $\begin{array}{l}\text { Alveolar tissue, pulmonary } \\
\text { aterial wall (media } \\
100 \mu \mathrm{m} \text { thick) }\end{array}$ & $\begin{array}{l}\text { Opacity in left } \\
\text { lower zone }\end{array}$ & $\begin{array}{l}\text { Haematoma in left lower } \\
\text { lobe }(3 \times 3 \times 4 \mathrm{~cm}) ; 100 \mathrm{ml} \\
\text { of blood in left pleural } \\
\text { cavity }\end{array}$ & \\
\hline 2 & Crocodile jaw & $\begin{array}{l}\text { Pulmonary arterial wall } \\
\text { (media } 100 \mu \mathrm{m} \text { thick) }\end{array}$ & Normal & No abnormality detected & \\
\hline 3 & - & - & - & - & $\begin{array}{l}\text { Impossible to float balloo } \\
\text { catheter into pulmonary } \\
\text { artery }\end{array}$ \\
\hline 4 & Fenestrated cups & $\begin{array}{l}\text { Alveolar tissue, pulmonary } \\
\text { arterial wall (media } \\
30 \mu \mathrm{m} \text { thick) }\end{array}$ & Not done & $\begin{array}{l}\text { Small tear on surface of } \\
\text { left lower lobe; no } \\
\text { significant pulmonary } \\
\text { haematoma; } 50 \text { ml of } \\
\text { blood in left pleural } \\
\text { cavity }\end{array}$ & $\begin{array}{l}\text { Died } 30 \text { min after } \\
\text { procedure }\end{array}$ \\
\hline 5 & Fenestrated cups & $\begin{array}{l}\text { Pulmonary arterial wall } \\
\text { (media } 380 \mu \mathrm{m} \text { thick) }\end{array}$ & Normal & No abnormality detected & \\
\hline 6 & Fenestrated cups & $\begin{array}{l}\text { Pulmonary arterial wall } \\
\text { (media not measurable) }\end{array}$ & Normal & No abnormality detected & \\
\hline 7 & Fenestrated cups & $\begin{array}{l}\text { Pulmonary arterial wall } \\
\text { (media } 180 \mu \mathrm{m} \text { thick) }\end{array}$ & Normal & No abnormality detected & \\
\hline 8 & Fenestrated cups & $\begin{array}{l}\text { Alveolar tissue, pulmonary } \\
\text { arterial wall (media } \\
110 \mu \mathrm{m} \text { thick) }\end{array}$ & Normal & $\begin{array}{l}\text { Intrapulmonary haematoma } \\
\text { ( } 2 \mathrm{~cm} \text { diameter); } \\
\text { pleura intact }\end{array}$ & \\
\hline 9 & Cutting needle & Alveolar tissue & Normal & $\begin{array}{l}\text { Intrapulmonary haematoma } \\
\text { ( } 1.5 \mathrm{~cm} \text { diameter); } \\
\text { pleura intact }\end{array}$ & \\
\hline 10 & Cutting needle & $\begin{array}{l}\text { Alveolar tissue, pulmonary } \\
\text { arterial wall (media } \\
75 \mu \mathrm{m} \text { thick) }\end{array}$ & Normal & $\begin{array}{l}\text { Intrapulmonary haematoma } \\
\text { (1 cm diameter); } \\
\text { pleura intact }\end{array}$ & \\
\hline 11 & Cutting needle & $\begin{array}{l}\text { Alveolar tissue, peribronchial } \\
\text { tissue containing bronchial } \\
\text { arterioles, pulmonary arterial } \\
\text { wall (media } 110 \mu \mathrm{m} \text { thick) }\end{array}$ & Normal & $\begin{array}{l}\text { Two intrapulmonary } \\
\text { haematomas (1 and } 1.5 \mathrm{~cm} \\
\text { diameter); pleura intact }\end{array}$ & \\
\hline 12 & Cutting needle & Alveolar tissue & Normal & $\begin{array}{l}\text { One intrapulmonary } \\
\text { haematoma ( } 1.5 \mathrm{~cm} \\
\text { diameter); pleura intact }\end{array}$ & \\
\hline 13 & Cutting needle & $\begin{array}{l}\text { Alveolar tissue, peribronchial } \\
\text { tissue containing } \\
\text { arterioles }\end{array}$ & Normal & $\begin{array}{l}\text { One intrapulmonary } \\
\text { haematoma }(1.5 \mathrm{~cm} \\
\text { diameter); pleura intact }\end{array}$ & \\
\hline 14 & Cutting needle & $\begin{array}{l}\text { Alveolar tissue, pulmonary } \\
\text { arterial wall (media } \\
170 \mu \mathrm{m} \text { thick) }\end{array}$ & Normal & $\begin{array}{l}\text { Two intrapulmonary } \\
\text { haematomas ( } 1.5 \mathrm{~cm} \\
\text { diameter); pleura intact }\end{array}$ & \\
\hline
\end{tabular}

about $1-1.5 \mathrm{~cm}$ in diameter (fig 3). On two occasions (in pigs 11 and 14) when biopsy specimens were obtained from two separate sites two haematomas developed. There was subpleural bruising, but the pleura in all instances was intact.

\section{Discussion}

As with other transplanted organs, the diagnosis of lung rejection can be made only with certainty by histological examination of lung tissue. Lymphocytic infiltration of the interstitium of the lung, perivascular cuffing by round cells, and the presence of alveolar fibrinous exudates (singly or in combination) have been recognised as essential criteria for making such a diagnosis. ${ }^{67}$ Koerner et al compared three methods of lung biopsy in the diagnosis of rejection after unilateral lung transplantation in 22 mongrel dogs. ${ }^{8}$ The diagnostic yield was $49 \%$ for the transthoracic cutting needle and $100 \%$ for open lung biopsy. A surprising feature, however, was that the diagnosis of lung rejection could not be made in any of the transbronchial specimens. These specimens showed lymphocytic infiltration of lung parenchyma, but the perivascular cuffing with round cells could not be seen.

With these considerations in mind we decided to explore the development of a new technique for lung biopsy that could be adapted to the clinical diagnosis of rejection in recipients of heart-lung transplants. The transvenous approach seemed to have the ideal characteristics for a repeatable biopsy procedure. It could be carried out percutaneously at the same time and with the same frequency as transvenous cardiac biopsy, which is currently used routinely for the diagnosis of cardiac rejection. It would also help to avoid 


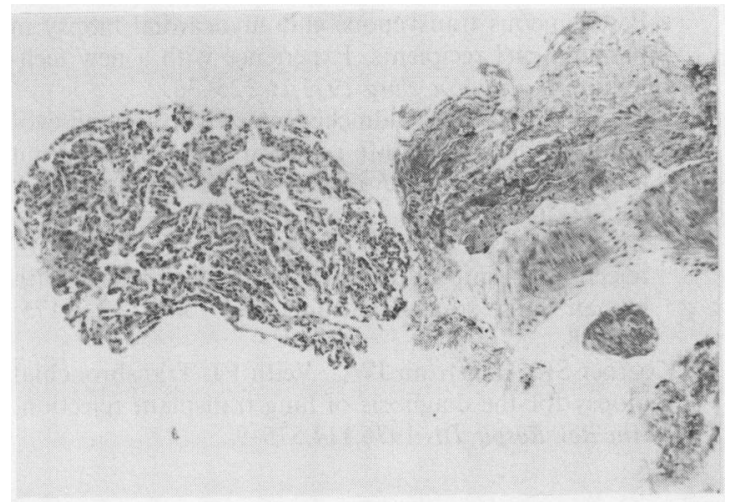

(a)

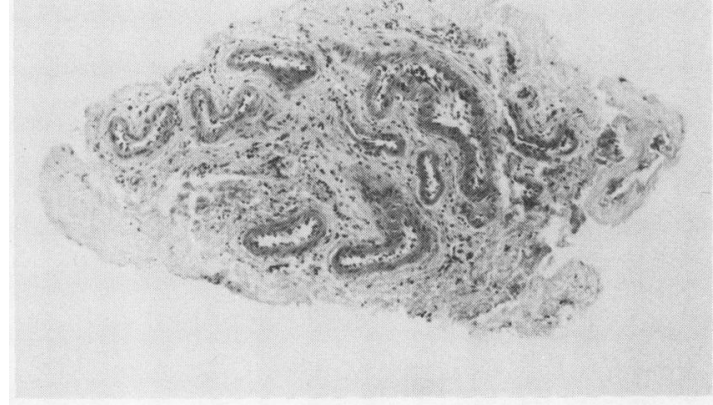

(b)

Fig 2 (a) Alveolar tissue and pulmonary arterial wall obtained by transvenous approach with the cutting needle forceps. (Haematoxylin and eosin.) (b) Peribronchiovascular tissue obtained by transvenous approach with the cutting needle forceps. (Haematoxylin and eosin.)

the need for bronchoscopic biopsy, which is particularly hazardous in the early postoperative period, when the healing of the tracheal anastomosis is not secure.

Our experimental work has demonstrated the feasibility of this procedure in animals. Complications were few and there was good success in obtaining pulmonary tissue in the vicinity of peripheral pulmonary arterial radicles, where histological evidence of pulmonary rejection might be more easily detected. The single death in our experiment occurred shortly after the procedure. The small amount of blood in the pleural cavity suggests that blood loss was an unlikely cause of death. The small tear on the surface of the lung could have resulted in a tension pneumothorax, although the possibility of cardiac dysrhythmia could not be ruled out. As with transbronchial lung biopsy, pneumothorax is a potential complication of transvenous lung biopsy. The incidence of this compli-

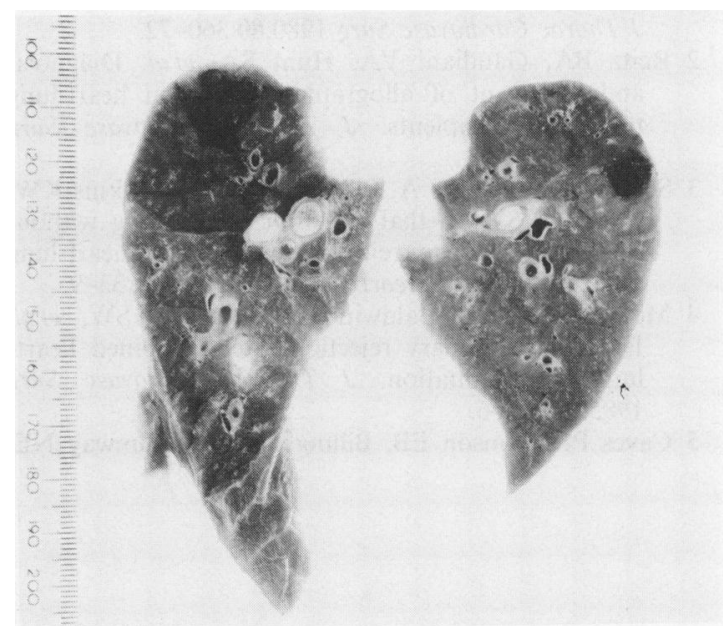

Fig 3 Cut sections of lungs showing intrapulmonary haematomas at two sites where transvenous biopsy samples were taken with the cutting needle forceps.

cation among heart-lung transplant recipients, however, would be expected to be low because of postoperative pleural adhesions. Of more concern is the possibility of pulmonary haemorrhage. Our study has shown that with the fenestrated cups or the cutting needle biopsy forceps used transvenously the intrapulmonary haematomas measured $1-2 \mathrm{~cm}$ in diameter, and with no evidence of haemorrhage into the airways.

We are currently investigating the use of transvenous lung biopsy in experimental lung transplantation, and we believe that this technique could be considered for use in clinical practice in the future. The major potential application lies in its use in recipients of heart-lung transplants for the diagnosis of rejection. Conceivably the application of this procedure could be extended to patients with acute diffuse lung disease of unknown aetiology, especially those with hypoxaemia, in whom bronchoscopic procedures are associated with a high morbidity rate.

We would like to express our thanks to Alan Press and David Wills of Kimal Scientific Ltd for their expert advice and the supply of specially designed equipment. Our thanks also go to David Buist and Hugh Edger of the Huntingdon Research Centre, and to Richard Kingshott, Chief Medical Scientific Officer at Papworth Hospital. We are also most grateful to Pam Norman for the excellent secretarial work.

\section{References}

1 Reitz BA, Burton NA, Jamieson SW, et al. Heart and lung transplantation. Autotransplantation and allotransplantation in primates with extended survival. 
J Thorac Cardiovasc Surg 1980;80:360-72.

2 Reitz BA, Gaudiani VA, Hunt SA, et al. Diagnosis and treatment of allograph rejection in heart-lung transplant recipients. $J$ Thorac Cardiovasc Surg 1983;85:354-61.

3 Scott WC, Haverich A, Billingham ME, Dawkins KW, Jamieson SW. Lethal rejection of the lung without significant cardiac rejection in primate heart-lung allotransplants. J Heart Transplant 1984;iv:33-9.

4 McGregor CGA, Baldwin JC, Jamieson SW, et al. Isolated pulmonary rejection after combined heartlung transplantation. $J$ Thorac Cardiovasc Surg 1985;90:623-6.

5 Caves PK, Stinson EB, Billingham M, Shumway NE.
Percutaneous transvenous endomyocardial biopsy in human heart recipients. Experience with a new tech-ฮ̄ nique. Ann Thorac Surg 1973;16:325-36.

6 Veith FJ, Sinha SBP, Blümcke S, et al. Nature and evolution of lung allograft rejection with and without immunosuppression. J Thorac Cardiovasc Surg 1972; 63:509-20.

7 Veith FJ, Hagstrom JWC. Alveolar manifestations of rejection: an important cause of the poor results with $\vec{\omega}$ human lung transplantation. Ann Surg 1972;175:336-48.

8 Koerner SK, Hagstrom JWC, Veith FJ. Transbronchial biopsy for the diagnosis of lung transplant rejection.. Am Rev Respir Dis 1976;114:575-9. 